\title{
Incidence, Seasonal and Geographical Patterns of Juvenile-Onset Insulin-Dependent Diabetes Mellitus in Denmark
}

\author{
B. Christau ${ }^{1}$, H. Kromann ${ }^{1}$, O. Ortved Andersen ${ }^{2}$, M. Christy ${ }^{1}$, K. Buschard ${ }^{3}$, K. Arnung 4 , \\ I. Højland Kristensen ${ }^{5}$, B. Peitersen ${ }^{6}$, J. Steinrud ${ }^{5}$, and J. Nerup ${ }^{1}$ \\ ${ }^{1}$ Steno Memorial Hospital, Gentofte, ${ }^{2}$ Medical Department E, Frederiksberg Hospital, Copenhagen, \\ ${ }^{3}$ Medical Department, Hvidovre Hospital, Hvidovre, ${ }^{4}$ Medical Department F, Herlev Hospital, Herlev, ${ }^{5}$ Departments of Medicine \\ and Pediatrics, Frederiksborg County Hospital, Hillerød, and ${ }^{6}$ Children's Hospital, Fuglebakken, Copenhagen, Denmark
}

Summary. The incidence, sex, seasonal and geographical patterns of juvenile-onset insulin-dependent diabetes mellitus (j. i. d. m.) were studied retrospectively on one third of the Danish population 1970-1974. The j. i. d. m. incidence remained fairly constant during the study period, the average being 13.2 per 100000 per year. The total number of boys exceeded the number of girls by 27 per cent. A marked peak of incidence was found at 12-14 years, earlier for females than for males. A seasonal variation in onset (diagnosis) of j. i. d. m. was observed with the lowest number of new cases in May-July. The j.i.d.m. incidence seemed to show socioeconomic differences, being highest in those parts of the survey area with lower status.

Key words: Incidence, seasonal variation, geographical pattern, sex-difference, epidemiology, juvenile-onset, insulin-dependent, diabetes mellitus.

Solidly ascertained incidence data on juvenile-onset diabetes mellitus are sparse. Bloom and co-workers [1] reported an incidence of 7.67 per 100000 per year in the U. K. in 1975 and described the influence of age, sex and seasonal variation on the incidence.

The present study was undertaken in order to produce comparable data from Denmark.

\section{Material and Methods}

Denmark is well suited for epidemiological studies due to an ethnically uniform Caucasian, non-migrating cooperative population, a public health care system and an effective national register.
The study was based on two assumptions. First that every patient with newly diagnosed juvenile-onset insulin-dependent diabetes mellitus (j. i. d. m.) aged 0-29 years and diagnosed between January 1, 1970 and December 31, 1974 was referred to a hospital, and secondly that the referrals would be made to the in- or outpatient services of the paediatric and medical departments.

The survey area comprised the city of Copenhagen, the County of Copenhagen (suburban in character) and the County of Frederiksborg (partly rural and partly suburban in character). The area covers 1961 square kilometers (4.5 per cent of the Danish territory ${ }^{1}$ ) and contains a population of 1598754 (average of 1970-74) or 32 per cent of the total Danish population. The age group 0-29 years in the survey area comprised 716285 persons or 30.8 per cent of the total Danish population in this age group.

All hospital records of newly diagnosed insulindependent diabetics aged less than 30 at the time of diagnosis were collected. Name, date of birth, sex, date of diagnosis, and place of residence at diagnosis were noted for each patient. This sample of $474 \mathrm{pa}-$ tients comprised the analysed group of diabetics. The validity of the above-mentioned assumptions was checked by a questionnaire to the general practioners and the few specialists in private practice in the survey area. Official Danish statistical yearbooks were used as sources of data for calculations of the age-corrected incidences.

\section{Results}

The ascertainment was almost complete, since only five patients diagnosed in the survey period were

\footnotetext{
1 Greenland and The Faroe Islands excluded
} 
Table 1. The number of juvenile-onset insulin-dependent diabetics aged 0-29 years, diagnosed in the survey area 1970-74

\begin{tabular}{|l|c|c|c|}
\hline YEAR & MALE & FEMALE & TOTAL \\
\hline 1970 & 46 & 51 & 97 \\
\hline 1971 & 54 & 34 & 88 \\
\hline 1972 & 62 & 36 & 98 \\
\hline 1973 & 43 & 48 & 91 \\
\hline 1974 & 60 & 40 & 100 \\
\hline $1970-1974$ & 265 & 209 & 474 \\
\hline
\end{tabular}

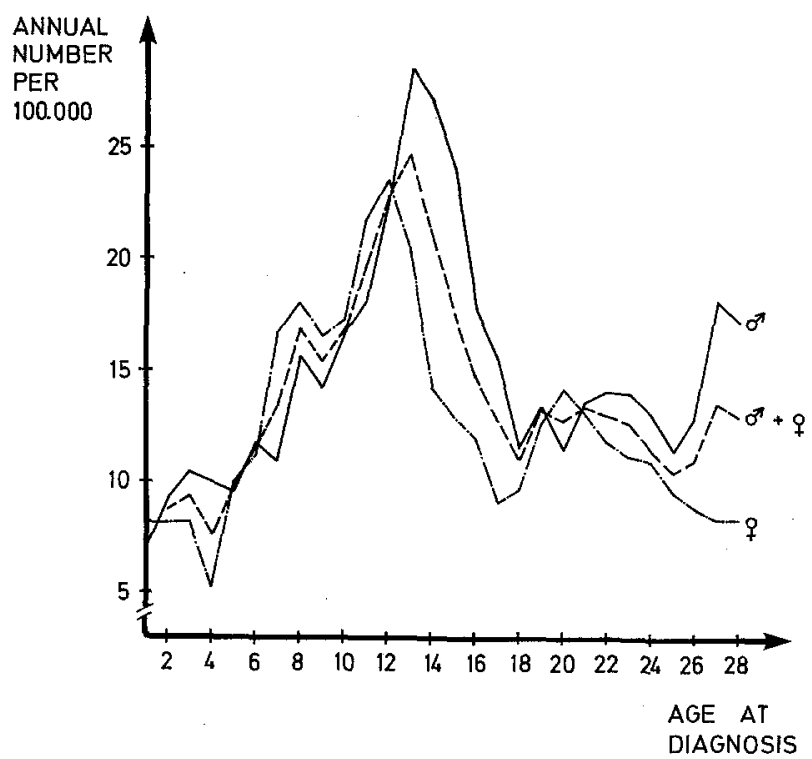

Fig. 1. Age variation in the incidence (annual number per 100000 ) of juvenile-onset insulin-dependent diabetes mellitus in Denmark. $(N=474)$

not included in the study by the method used. These five cases are omitted from the calculations.

A total of 474 cases of j. i. d. m. were registered during the five year period (Table 1). The total number of boys exceeded the number of girls by 27 per cent. The calculated age-corrected incidence of j. i. d. m. was found to be 13.2 per 100000 per year (for males 14.5 and 11.9 for females) (denominator in the equation was the total number across the whole age range involved). No major differences in age-corrected incidences between the age groups 0-14 and 15-29 years (Table 2) or between the three regions of the survey area were noted. Maximal year to year variation in incidence was 12.1 to 14.3.

When incidences for one year age groups were plotted in relation to age at diagnosis (Fig. 1), a marked peak incidence was demonstrated at ages 12
Table 2. Age corrected incidence (annual number per 100000) of j. i. d. m. for age groups $0-29$ years, $0-14$ years and $15-29$ years

\begin{tabular}{|l|c|c|c|c|}
\hline \multirow{4}{*}{$\begin{array}{l}\text { ANNUAL } \\
\text { NUMBER }\end{array}$} & AGE GROUP & MALE & FEMALE & TOTAL \\
\cline { 2 - 5 } & $0-14$ & 15.0 & 13.2. & 13.7 \\
\cline { 2 - 5 } PER 100000 & $15-29$ & 14.3 & 10.8 & 12.8 \\
\cline { 2 - 5 } & $0-29$ & 14.5 & 11.9 & 13.2 \\
\hline
\end{tabular}

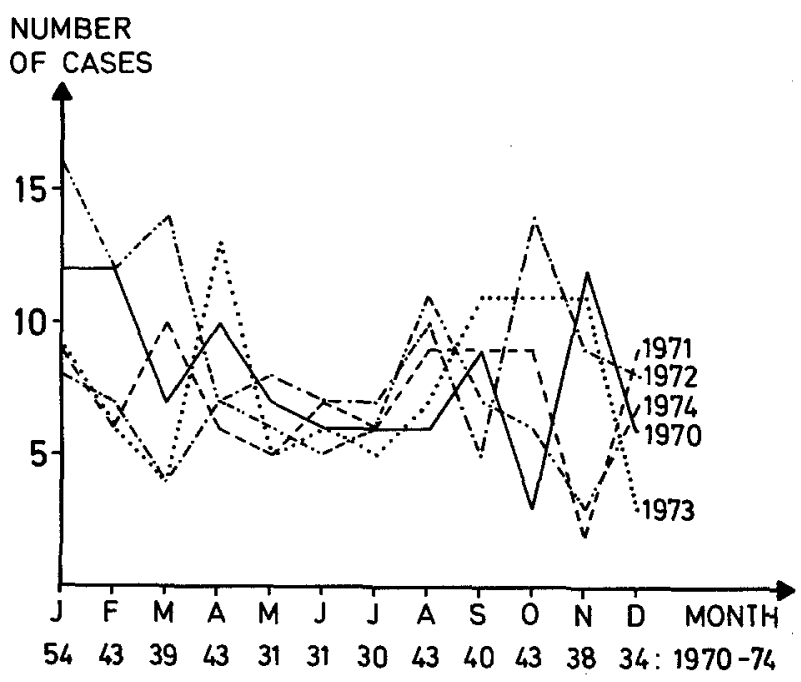

Fig. 2. Seasonal variation in the diagnosis of juvenile-onset insulin-dependent diabetes mellitus in Denmark in 1970-74

to 14 . The female peak preceded the male peak by one to two years. During early childhood the j. i. d. m. incidence gradually increased, while it remained fairly stable after the age of 17-18. Smaller peaks were present at age 7-9 and in the late twenties.

A seasonal variation (Fig. 2) with a reduction of incidence during May, June and July was found. Geographical or familial clustering of outbreaks of j. i. d. m. was not observed in this study.

A detailed analysis of the incidence data from the county of Copenhagen, however, showed a difference between the northern and southern part of the county, with most cases in the southern part. This difference in incidence between the two areas was due to a marked difference in incidence in the age group 0-14 years (20.0 and 10.5 in southern and northern area respectively). Table 3 demon- 
Table 3. Some socio-economic characteristics of the two areas of the Copenhagen county

\begin{tabular}{|l|c|c|}
\hline & AREA I & AREA II \\
\hline $\begin{array}{l}\text { INCIDENCES OF JUVENILE DIABETES MELLITUS (ANNUAL } \\
\text { NUMBER PER 100000) IN THE AGE GROUPS 0-14 YEARS }\end{array}$ & 10.5 & 20.0 \\
\hline \hline $\begin{array}{l}\text { THE AGE GROUP 0-14 YEARS IN PER CENT OF THE TOTAL } \\
\text { POPULATION }\end{array}$ & 23.9 & 27.9 \\
\hline $\begin{array}{l}\text { FIVE YEARS GROWTH RATE OF THE TOTAL POPULATION } \\
\text { (IN PER CENT) }\end{array}$ & -2.27 & +8.24 \\
\hline THE AVERAGE NUMBER OF PERSONS PER ROOM & 0.84 & 0.92 \\
\hline $\begin{array}{l}\text { NUMBER OF UNSKILLED WORKERS IN PER CENT OF THE } \\
\text { TOTAL POPULATION }\end{array}$ & 9.7 & 13.6 \\
\hline $\begin{array}{l}\text { NUMBER OF THE POPULATION WITH SCHOOL ATTENDANCE } \\
\text { II YEARS ( IN PER CENT) }\end{array}$ & 7.6 & 3.6 \\
\hline $\begin{array}{l}\text { NUMBER AF WOMEN WORKING AWAY FROM HOME } \\
\text { (IN PER CENT) }\end{array}$ & 145.000 & 62.500 \\
\hline $\begin{array}{l}\text { PROPERTY ACCORDING TO ASSESSMENT PER FAMILY } \\
\text { (IN DANISH CROWNS) }\end{array}$ & 38.4 & 42.1 \\
\hline
\end{tabular}

strates some socio-economic differences between the two areas of the Copenhagen county collected from official statistical sources.

\section{Discussion}

Adams [2] described as early as 1926 a seasonal variation of "acute diabetes" with most cases occurring in fall, winter and early spring. Later Gamble and Taylor [3] renewed the interest in the seasonal pattern of the onset of juvenile-onset diabetes mellitus by demonstrating a seasonal variation in the age group 0-19 years similar to that described by Adams.

The data from the prospective study conducted under the auspices of the British Diabetic Association [1] showed a similar seasonal pattern among 2000 0-15 year old newly diagnosed diabetics. In that material the 5-15 year subgroup accounted for the seasonal variations in onset.

A similar seasonal variation in the onset (diagnosis) of j. i. d. m. was demonstrated in the present study comprising ages 0-29 years. No differences could be demonstrated between subgroups. It was suggested by Gamble et al. [4] that the seasonal variation reflected a seasonal variation in certain infections, but unequivocal data to support this hypothesis have not been reported so far, and the seasonal pattern found in Great Britain and in Denmark might perhaps be explained in other ways (e. g. dietary changes and increased physical activity in the summer period. Low frequency of patientdoctor contacts at this time of the year).

The j. i. d.m. incidence found in the present study was higher than that of the British study [1]. Obviously this might reflect true incidence differences (13.2 and 7.67 respectively), but differences in degrees of ascertainment are more likely.

The number of males with j. i. d. m. found in this study was 27 per cent higher than the number of females. The male excess (in numbers) in the British study can be calculated to 12 per cent. Thus sex seems to influence in some way the development of j. i. d. m. In this context it is of interest that sex may affect the incidence of a viral infection [5] and its manifestations [6]. Also experimental diabetes can be more readily produced in male than in female animals [7] (Kromann et al. in preparation).

The incidence of j. i.d. m. varies with age. A small peak is perhaps present at 7-9 years and a main peak at 12-14 years, earlier for females than for males (12 and 13-14 years respectively).

It was claimed [8] that the incidence peaks were associated with puberty and growth spurts, but this was disputed by Bloom and co-workers [1] and neither does this hypothesis fit Danish conditions [9, 10]. However, it cannot be ruled out that hormonal changes in prepubertal years are of importance in relation to diabetes onset.

No geographical or familial clustering of cases was found in the present study. It was however of interest to observe that the incidence of j. i. d. m. was higher in the southern part of the Copenhagen 
county than in the northern part. This pattern was constantly present during the sampling period and was also observed in a one year prospective study in the same survey area (in preparation). This difference in incidence could be demonstrated for the age group 0-14 years only. It was reported from the United States that the prevalence of diabetes mellitus is associated in some way with income and educational level [11]. The mechanisms involved in the socio-economic associations are unknown so far.

The rather low concordance rate of juvenile-onset diabetes mellitus in identical twins [12], the detailed data on j. i. d. m., HLA association [13, 14] and the surprisingly low empirical risk of juvenile diabetes in first degree relatives of juvenile diabetics [15] suggest that environmental factors are of importance in the development of j.i. d. m. The seasonal variation demonstrated in both the British study [1] and this report, the influence of age on the incidence of j.i.d.m. and the possible socioeconomic impact on the outbreak of the disease, further support the importance of non-genetic environmental factors in the aetiology and pathogenesis of j. i. d. m.

Acknowledgements. The authors wish to thank the heads of the thirty-three Departments of Pediatrics and Medicine in the survey area, for cooperation and advice. Special thanks are due to the chief physicians of Hvidøre Hospital and the Department of Pediatrics, Glostrup Hospital, Copenhagen, for their generous support.

\section{References}

1. Bloom, A., Hayes, T.M., Gamble, D. R.: Register of newly diagnosed diabetic children. Br. Med. J. 1975 III, 580-583

2. Adams, F.: The seasonal variation in the onset of acute diabetes. Arch. Intern. Med. 37, 861-864 (1926)
3. Gamble, D. R., Taylor, K.W.: Seasonal incidence of diabetes mellitus. Br. Med. J. 1969 III, 631-633

4. Gamble, D. R., Kinsley, M.L., Fitzgerald, M.G., Bolton, R., Taylor, K.W.: Viral antibodies in diabetes mellitus. Br. Med. J. 1969 III, 627-630

5. Spicer, C.C.: The incidence of poliomyelitis virus in normal children aged 0-5 years. J. Hyg. (Camb.) 59, 143-159 (1961)

6. Lennette, E.H., Magoffin, R.L., Knouf, E. G.: Viral central nervous system disease. JAMA 179, 687-695 (1962)

7. Craighead, J.E., Steinke, J.: Diabetes mellitus-like syndrome in mice infected with encephalomyocarditis virus. Am. J. Pathol. 63, 119-134 (1971)

8. White, P.: Diabetes in childhood and adolescence, p. 61. Philadelphia: Lea and Febiger 1932

9. Andersen, E., Andersen, H., Hutchings, B., Peitersen, B., Rosen, J., Thamdrup, E., Wichmann, R., Nyholm, M.: Højde og vægt hos danske skolebørn 1971-72. Ugeskr. Læger 50, 2796-2802 (1974)

10. Andersen, E.: Skeletal maturation of Danish school children in relation to height, sexual development, and social conditions. Aarhus: Universitetsforlaget 1968

11. Diabetic Source Book. Public Health Service Publication 1168, pp. 49-53. Washington, D. C.: U.S. Government Printing Office 1968

12. Tattersall, R.B., Pyke, D.A.: Diabetes in identical twins. Lancet 1972 II, $1120-1125$

13. Nerup, J., Platz, P., Andersen, O. O., Christy, M., Lyngsøe, J., Poulsen, J.E., Ryder, L.P., Staub Nielsen, L., Thomsen, M., Svejgaard, A.: HL-A antigens and diabetes mellitus. Lancet 1974 II, 864-866

14. Cudworth, A.G., Woodrow, J.G.: Evidence for HL-A linked genes in "juvenile" diabetes mellitus. Br. Med. J. 1975 III, 133-135

15. Hansen, A. G., Degnbol, B.: Prevalence of diabetes mellitus among relatives of 187 patients with juvenile diabetes. Diabetologia 12, 396 (1976)

Received: December 2, 1976, and in revised form:

February 14, 1977

Dr. J. Nerup

Steno Memorial Hospital

Niels Steensens Vej 2

DK-2820 Gentofte

Denmark 